\title{
Efficacy of Aframomum melegueta and Zingiber officinale extracts on fungal pathogens of tomato fruit.
}

\author{
${ }^{1}$ Chiejina, Nneka V ${ }^{2}$. And $\mathrm{Ukeh}^{3}$, Jude $\mathrm{A}^{4}$. \\ ${ }^{1,2,3,4}$ Department of Plant Science and Biotechnology University of Nigeria, Nsukka.
}

\begin{abstract}
The inhibitory properties of the methanolic extracts of Aframomum melegueta and Zingiber officinale on the fungal pathogens isolated from tomato were investigated. The pathogens were Helminthosporium solani, Mucor piriformis, Penicillium digitatum and Aspergillus niger. Various concentrations of the extracts ranging from 0-30\% were separately added to PDA media. The pathogens were separately inoculated into the media and incubated for eight days. Antifungal effects of these extracts on the mycelial growth of the pathogens were significant at $P<0.05$ for all treatments. At 25\% concentration, the four pathogens were completely inhibited by Z. officinale extract. A. melegueta extract inhibited completely Helminthosporium solani and Mucor piriformis, while Penicillium digitatum and Aspergillus niger were $92.99 \%$ and $89.09 \%$ inhibited respectively at $25 \%$ concentration of the extract. The in vitro inhibitory effects of these extracts indicated that they can be used for the control of tomato fruit rot. It may be necessary to use them in prolonging the shelf-life of fresh tomato fruit and some other fruits.
\end{abstract}

Keywords: Efficacy, Extract, Tomato fruit, Aframomum melegueta, Zingiber offficinale, in vitro.

\section{Introduction}

Fungal infections are one of the major causes of post harvest rots of fresh fruits and vegetables whether in transit or storage. They cause significant economic losses in the commercialization phase, and are rendered unfit for human consumption. (Janardhana et al., 1999; Marin et al., 1999).

Agricultural practices have been replaced by the use of chemicals for the management of plant diseases. This has no doubt increased crop production but with the attendant deterioration of the environment and human health. In addition to killing target pathogens, pesticides may also kill various beneficial organisms and their toxic effects can persist in the soil (Onuegbu, 2002). The increasing incidence of resistance of pathogens to chemicals has recently been a source of concern.

In Nigeria, for instance, about $98 \%$ of the food consumed is produced by the local farmers Most of these farmers are not educated and therefore in most cases cannot practise the various control measures recommended for disease control. In addition to these inadequacies, most of the chemicals are not available and where they are, they are very expensive. These problems have necessitated the search for alternatives to synthetic fungicides. Among the various alternatives, natural plants products that are bio-degradable, ecologically friendly and readily available have therefore been sort by scientist's worldwide (Amadioha, 2000 and Okigbo, 2009).

Extracts obtained from many plants have recently gained popularity and scientific interest for their antifungal activities (Lee et al., 2007; Verastegui et al., 2008; Santas et al., 2010). Reports on the antimicrobial properties of plant extracts containing different classes of phenolic compounds abound. Phenolic compounds represent a rich source of preservatives that have been explored for a long time as postharvest alternative control measures to fungicides (Lattanzio, 2003; Schena et al., 2008).

Other research workers (Amadioha and Obi, 1999; Amadioha, 2000 and Okigbo, 2009) see the significance of fungicides of plant origin as possible means of fungal disease control in fruits and vegetables as they are easily biodegradable and non toxic to humans. This investigation was therefore targeted at the in vitro inhibitory effects of two tropical, indigenous plant extracts of Zingiber officinale and Aframomum melegueta on post harvest fungal rot of tomato fruit.

\section{Materials And Methods}

Collection of Plant Materials: The seeds of Alligator pepper, Aframomum melegueta and rhizomes of ginger, Zingiber officinale were collected from Obudu in Cross River State. Fungal pathogens were isolated from diseased tomato fruits obtained from Nsukka in Enugu State using the conventional methods of Okigbo et al. (2009). Identification was done in Plant Science and Biotechnology department, University of Nigeria, Nsukka.

Pathogenicity Tests: Pathogenicity tests were carried out using the techniques of Okigbo et al. (2009). Healthy tomato fruits were washed in sterile distilled water and surface sterilized with $0.1 \%$ mercury chloride solution. A $5 \mathrm{~mm}$ diameter cork borer was used to cut discs from the fruits (three discs per fruit) and cultures of the isolate 
discs were introduced into the holes and replaced with the discs. These were kept for 24 to 48 hours. The inoculated fruits established symptoms on the second day and tissue segments from the infected fruits were cultured. Pure cultures were identified according to Barnett and Hunter, (1999) and Alexopoulos et al. (2002).

Preparation of Plant Extracts: The extraction process used was the soaking method. One hundred grammes of each dried powdered sample was soaked in $1000 \mathrm{ml}$ of $70 \%$ methanol for 24 hours. The samples were each filtered twice through two layers of sterile cheese cloth and the filtrate collected in a round bottom flask. Each filtrate was concentrated to semi-solid using rotary evaporator. The extracts were reconstituted by dissolving $10 \mathrm{~g}$ each of the extract in $20 \mathrm{ml}$ of sterile distilled water and stored in sterile conical flasks at $12^{\circ} \mathrm{C}$ in the refrigerator for further analysis.

Effects of Plant Extracts on Fungal Growth: A modified method of Amadioha and Obi (1999) was used to determine the effect of the extracts on fungal growth. Four equal sections were created in each Petri-dish by drawing two perpendicular lines at the bottom of each plate, the point of intersection being the centre of the plate. PDA was dispensed into the plates and $2 \mathrm{ml}$ of each plant extract at the different concentrations $(5,10,15$, 2025 and 30\%) were separately introduced into the Petri-dishes. The plates were rotated gently to enable even dispersion of the extracts. A $3 \mathrm{~mm}$ disc of 5day-old pure cultures of each isolate was inoculated into the plates just at the point of intersection of the two lines drawn at the bottom of the Petri-dishes. Control experiments were set up without plant extracts. Fungitoxicity was recorded as percentage inhibition of fungal growth and calculated according to the formula:

$$
\begin{aligned}
& \text { Percentage }(\%) \text { of mycelial zone inhibition } \mathrm{PI}=\frac{F 1-F 2}{F 1} \times 100 \\
& \begin{aligned}
\text { Where } \mathrm{PI} & =\text { Percentage inhibition of fungal growth } \\
\mathrm{F}_{1} & =\text { Fungal growth in control plates (PDA only) } \\
\mathrm{F}_{2} & =\text { Fungal growth in treatment plates. }
\end{aligned}
\end{aligned}
$$

\section{Results And Discussion}

The fungal pathogens isolated were identified as Aspergillus niger, Penicillium digitatum, Helminthosporium solani and Mucor piriformis. The results of this study revealed that the fungi were responsible for the post harvest rot of tomato fruits in Nsukka as evidenced by the Pathogenicity tests. The fungal spores of these pathogens could be air-borne and therefore spread by wind and may land on susceptible fruits like tomato and other plants. The pathogens (A. niger, Mucor spp, and P. digitatum) were reported by Okigbo, et al. (2009) to cause rot of cassava. Also Mehrotra and Aggarwal (2003) reported Helminthosporium spp as pathogens of post harvest rot of tomato, which is in agreement with the finding of this study.

The inhibitory effects of A. melegueta and Z. officinale on the isolated pathogens are shown in (Figures 1- 6). The efficacy of the two plant extracts against the tomato fruit rot fungi was tested in vitro. The results showed that, the extracts significantly $(\mathrm{P}<0.05)$ inhibited the mycelial growth of the fungal pathogens at the different concentrations tested and the rate of inhibition differed from one extract to the other.

Z. officinale extract was more fungistoxic to these pathogens than A. melegueta at concentrations of 5$20 \%$. The inhibitory effect of the plant extracts at $10 \%$ concentration as shown in Figure 2 has Z. officinale extract with the highest percentage of inhibition of all the tested organisms than A. melegueta extract. At $15 \%$ concentration of each extract, $M$. piriformis and $H$. solani was the most inhibited by the plant extracts, while $A$. niger was the least inhibited (Figure 3). However, percentage inhibition of the mycelial growth of all the tested pathogens took a similar trend in all the plant extracts. Increase in antifungal activity was observed with the corresponding increase in the concentrations of all the plant extracts (Figures 1-6). The differences in the fungitoxic potentials between these plant extracts may be attributed to the susceptibility of each of the fungal pathogens to the different concentrations of the extracts. This agrees with the results of some workers like Amadioha, (2000) and Okigbo and Nmeka, (2005).

Ilondu et al. (2001) reported that some plants contain phenolic substances and essential oils, which are inhibitory to micro-organisms. The presence of these compounds in these extracts has been reported to be responsible for their antifungal properties (Ahmed and Stoll, 1996). These antifungal properties control various pests including fungi while the extract of ginger rhizomes is specially valued for their effectiveness against fungi (Ahmed and Stoll, 1996). 


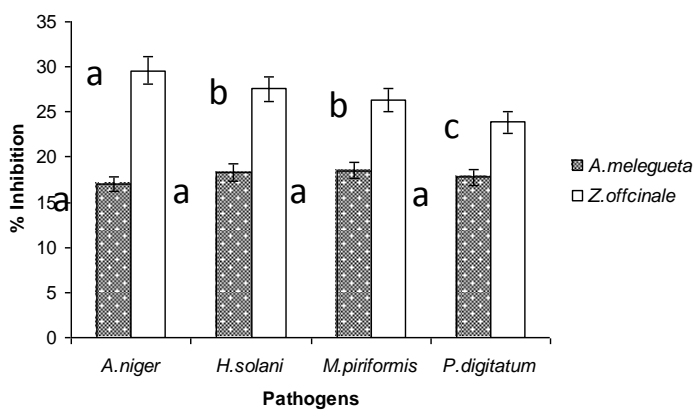

Figure 1: Inhibitory effect of extracts at $5 \%$ concentration on pathogens Mean bars with different alphabets are significantly different at $(\mathrm{P}<0.05)$.

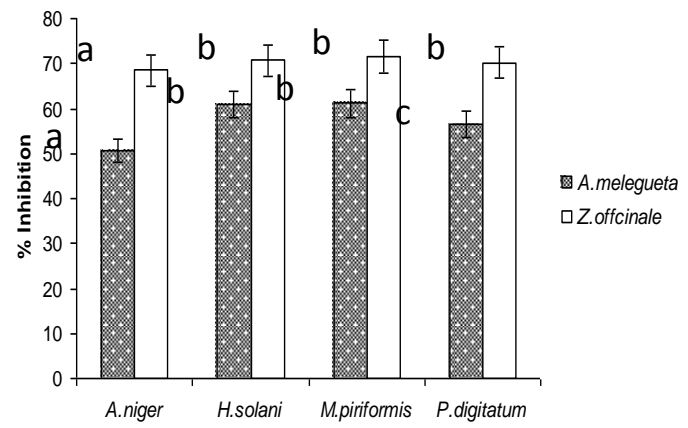

Figure 3: Inhibitory effect of extracts at $15 \%$ concentration on pathogens Mean bars with different alphabets are significantly different at $(\mathrm{P}<0.05)$.

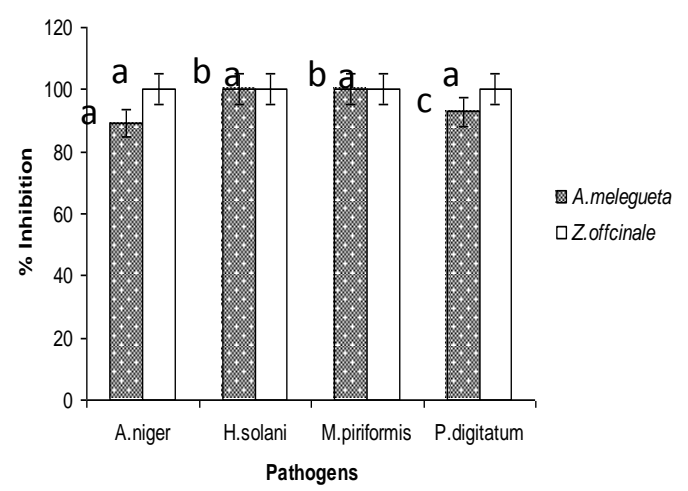

Figure 5: Inhibitory effect of extracts at $25 \%$ concentration on pathogens Mean bars with different alphabets are significantly different at $(\mathrm{P}<0.05)$.

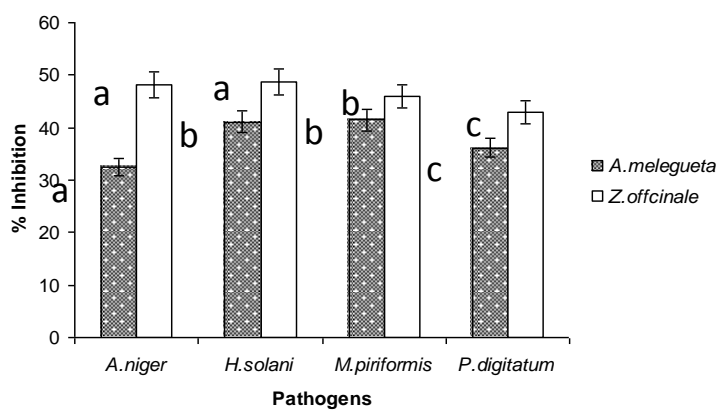

Figure 2: Inhibitory effect of extracts at $10 \%$ concentration on pathogens Mean bars with different alphabets are significantly different at $(\mathrm{P}<0.05)$.

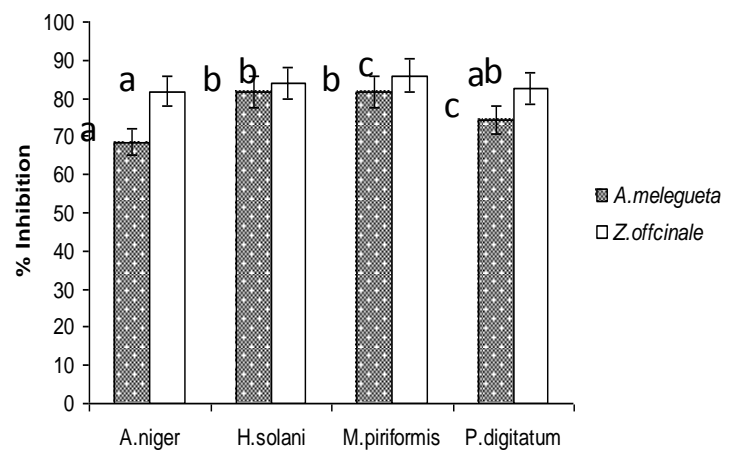

Pathogens

Figure 4: Inhibitory effect of extracts at $20 \%$ concentration on pathogens Mean bars with different alphabets are significantly different at $(\mathrm{P}<0.05)$.

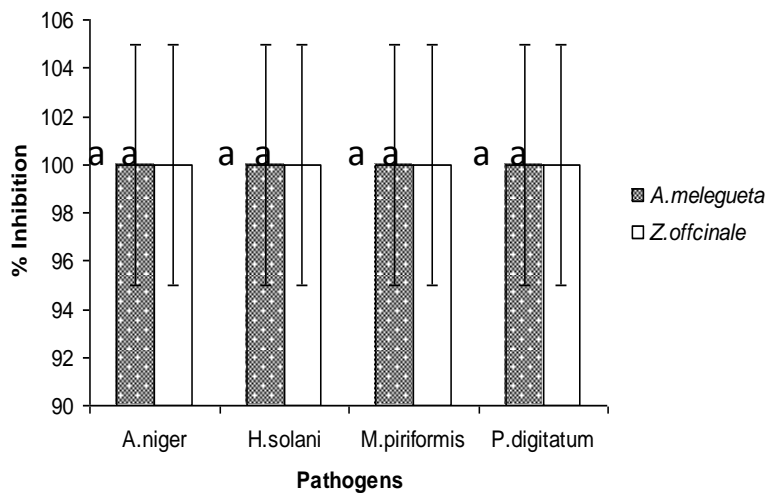

Figure 6: Inhibitory effect of extracts at 30\% concentration on pathogens

Mean bars with different alphabets are significantly different at $(\mathrm{P}<0.05)$

The plant extracts differed significantly in their potential to inhibit the growth of these fungal pathogens. Complete inhibition of the growth of all the pathogens was achieved with Z. officinale extract at $25 \%$ concentration but not with and A. melegueta extract (Figure 5) A. melegueta had total inhibition of all the pathogens at 30\% concentration (Figure 6) Concentrations of the extracts had significant effects on the mycelial growth of these pathogens $(P<0.05)$. Generally, mycelial growth decreased with increased in each of the plant extract concentrations. Also all the tested extracts concentrations inhibited significantly the mycelial growth of the pathogens. It is note worthy that, at all tested concentrations, Z. officinale was more inhibitory than $A$. melegueta. The inhibitory potency of the plant extracts may be attributed to the phytochemical compounds like tannins, alkaloids, flavonoids and saponins in them as reported by Chiejina and Ukeh (2012). This is in 
agreement with the works of Amadioha and Obi, (1999) and Udo et al. (2001) who reported the high potency of plant extracts containing the same bio-active compounds could be use for the control of fungal pathogens of plants. The inhibitory effects of $Z$. officinale and A. melegueta methanolic extracts at six different concentrations were evaluated in order to develop the cheaper methods of controlling the rot of tomato and other fruits.

The greater efficiency of $Z$. officinale may be due to the high contents of alkaloids it contains (Chiejina and Ukeh, 2012), since alkaloids are ranked as the most efficient therapeutically significant plant substances (Okwu, 2004). This result is in line with the work of Chuku et al. (2010) on the use of ginger and garlic in controlling fungal spoilage of tomato. Their result revealed that the growth of the fungi was completely inhibited at a higher concentration of 3 grams $/ 20 \mathrm{ml}$ of ginger powder than at the lower concentrations $(1 \mathrm{~g}$ and $2 \mathrm{~g} / 20 \mathrm{ml})$ and garlic powder was not effective.

\section{Conclusion}

Preservation of fruits and vegetables is of great importance because it makes provision for delayed use and eliminates wastage. Due to the perishable nature of tomato, post harvest loss is high. Therefore, production must go hand in hand with proper preservation and storage. The inhibitory activity of these extracts suggests their fungitoxic ability on these fungal pathogens. The findings of the present investigation are pointed to the crop protection strategies against fungal pathogens. The results of this study are important steps towards developing plant based fungicides which are ecofriendly for the management of fungal rot in fruits and the development of commercial formulations of botanicals. This investigation demonstrates the potentials of $Z$. officinale and A. melegueta as potential alternatives to synthetic fungicides in the control of post harvest rot of tomato fruits.

\section{References}

[1] Ahmed, S. and G. Stoll, (1996). Biopesticides. In: Biotechnology; Building on Farmers' Knowledge. Macmillan Education Ltd, Bunders, J., B. Haverkort and W. Hiemstra (Eds.). London, pp: 52-79.

[2] Alexopoulos, C.O., Mims, C.W. and Blackwell, M. (2002). Introductory Mycology. $4^{\text {th }}$ ed. John Wiley and Sons Inc. Singapore. $869 \mathrm{pp}$.

[3] Amadioha, A.C (2000). Fungitoxic effects of some leaf extracts against Rhizopus oryzae causing tuber rot of potato. Archives of Phytopatholpflanzo 34:1-9.

[4] Amadioha, A.C and Obi, V.I (1999). Control of Anthranose diseases of Cowpea by Cymbopogon cunitus and Ocimum gratissimum. Acto Phytopathology and Entomology 85: 89.

[5] Barnett, H.L. and Hunter, B.B. (1999). Illustrated Genera of Imperfect Fungi, $4^{\text {th }}$ ed. The American Phytopathological Society . St. Paul, Minnessota,USA, 218pp.

[6] Chiejina, N.V and Ukeh, J.A (2012). Antimicrobial properties and phytochemical analysis of methanolic extracts of Afrmomum melegueta and Zingiber officinale on fungal diseases of tomato fruit. Journal of Natural Sciences Research 2(6):10-15.

[7] Chuku, E.C, Osakwe, J.A and Daddy-West, C. (2010). Fungal spoilage of tomato (Lycopersicon esculentum Mill), using garlic and ginger. Scientia Africana, 9(2): 42-50.

[8] Ilondu, E.M., B.O. Ejechi and J.A. Souzey, (2001). Microbial stability of jam prepared from velvet tamarind and preserved by combined processes. Nigerian Journal of Microbiology, 5: 93-96.

[9] Janardhana, G.R., Raveesha, K.A. and Shetty, H.S. (1999). Mycotoxin contamination of maize grains grown in Karnataka (India). Food Chemical Toxicology 37: $863-868$

[10] Lattanzio, V. (2003). Bioactive polyphenols: their role in quality and storability of fruit and vegetables. Journal of Applied Botany. $77,128-146$.

[11] Lee, S.H., Chang, K.S., Su, M.S., Huang, Y.S. and Jang, H.D. (2007). Effects of some Chinese medicinal plant extracts on five different fungi. Food Control 18:1547-1554.

[12] Marin. S., Homedes, V., Sanchis, V., Ramos, A.J. and Magan, N. (1999). Impact of Fusarium moniliforme and F. proliferatum colonisation of maize on calorific losses and fumonisin production under different environmental conditions. Journal of Stored Product Research 35: 15 - 26.

[13] Mehrotra, R. S. and Aggarwal, A. (2003). Plant pathology. $2^{\text {nd }}$ Ed. Tata McGraw- Hill. New Delhi. 846pp.

[14] Okigbo, R.N (2009). Variation in phytochemical properties of selected fungicidal aqueous extract of some plant leaves in Kogi State, Nigeria. American-Eurasian Journal of sustainable Agriculture 3(3):407-409.

[15] Okigbo,R.N. and Nmeka, I.A. (2005). Control of yam tuber rot with leaf extracts of Xylopia aethiopica and Zingiber officinale. African Journal of Biotechnology 4(8): 804-807.

[16] Okigbo, R.N., Ramesh, P. and Achusi, C.T (2009). Post-Harvest Deterioration of Cassava and its Control using extracts of Azadirachta indica and Aframomum melegueta. EJournal of Chemistry. 6(4):1274-1280

[17] Okwu, D.E. (2004). Phytochemicals vitamins content of Indigenous spices of South Eastern Nigeria. Journal of Sustain Agricultural Environment.6:30-34.

[18] Onuegbu, B.A (2002). Fundamentals of Crop Protection. Agro-science Consult and Extension Unit, RSUT. 237pp.

[19] Santas, J., Almajano, M.P. and Carbo, R. (2010. Antimicrobial and antioxidant activity of crude onion (Allium cepa L.) extracts. International Journal of Food Science Technology 45, 403-409.

[20] Schena, L., Nigro, F.and Ippolito, A. (2008). Natural antimicrobials to improve storage and shelf-life of fresh fruit vegetables and cut flowers. In: Microbial Biotechnology in Horticulture, vol. 2. Science Publisher, Enfield, NH, Ray, R.C. and Ward, O.P. (Eds.), USA, pp. 259-303.

[21] Udo, S.E., Madunagu, B.E and Isemin, C.D (2001). Inhibition of growth and sporulation of fungal pathogens on sweet potato and yam by garlic extract. Nigerian Journal of Botany 14:35-39.

[22] Verástegui, A., Verde, J., García, S., Heredia, N., Oranday, A. and Rivas, C. (2008). Species of agave with antimicrobial activity against selected pathogenic bacteria and fungi. World Journal Microbiology and Biotechnology 24: 1249-1252. 